DOI 10.31554/2304-1838-2021-14-81-88

УДК 821

ББК 83.3

Мунхбаяр Б.

Опыт изучения рукописи «Харанхуй хад» Д. Нацагдоржа

Аннотация. Статья посвящена творчеству выдающегося монгольского ученого и писателя Д. Нацагдоржа. На примере изучения рассказа «У темных скал» выявлено, что для грамотной организации содержания автором искусно использованы сны и предчувствия. Исследователями принято характеризовать данное произведение как: 1) произведение модернизма и постмодернизма в связи с использованием новых западных стилей; 2) произведение, созданное на основе метода символизма; 3) рассказ содержит в себе поэтику (архетип) мифа. Данные выводы основаны на анализе имени главной героини рассказа - Нина или Ина.

Ключевые слова: Нацагдорж, монгольская литература, рукопись, символизм.

Munkhbayar Baatarzhav

\title{
Experience of studing D. Natsagdorzhi's manuscript of «Kharankhyi khad»
}

Abstract. In the short story 'Dark Cliff' D. Natsagdorzhi uses dreams and intuition for arranging its content. Therefore, scholars evaluate the 'Dark Cliff' as: 1 . The work that is regarded as modern and postmodernist work due to the use of new western writing styles.

2. The work created in a symbolic writing method.

3. The short story contains the poetic of mythic (Archetype) literary thought.

This conclusion is done on the analysis of the name Nina or Ina, the main hero of the story.

Keywords: Natsagdorzhi, Mongolian literature, manuscript, symbolism.

Мөнхбаяр Б.

Д. Нацагдоржийн зохиолын гар бичмэл дээр ажилласан туршлага ба үнэ цэн

Д. Нацагдорж “Харанхуй хад” өгүүллэгтээ зүүд, зөн совинг ашиглан, уран сэтгэмжээр үйл явдлыг бичсэн байна. Тийм учраас, судлаачид “Харанхуй хад” өгүүллэгийн талаар: 
1. Энэ өгүүллэг нь өрнө дахины уран зохиолын шинэ хэв маяг, модернизм, постмодернизмын маягтай зохиол юм.

2. Энэ өгүүллэг нь символизмын аргуудыг хэрэглэсэн.

3. Энэ өгүүллэг нь архитеп, домог үлгэрийн уран сайхны сэтгэлгээ (poetic of myth, мифопоэтик)-г шигтгэж өгсөн гэх зэрэг санал дэвшүүлжээ. Ингэж үзсэний учир нь, өгүүллэгийн гол дүрийг “Nina”, эсвэл “Ina” гэж ойлгосноос болсон байна. Энэ өгүүлэлд энэ тухай задлан шинжилжээ.

Өвөрмонголын Багшийн их сургуулийн Монгол судлалын дээд сургуулийн профессор Дорнотэнгэр нэгэнтээ: «Монгол Улсын алдарт яруу найрагч, орчин үеийн уран зохиолыг үндэслэгч Д. Нацагдорж бол ховорхон олддог уран зохиолын авъяас билигтэн мөн. Хурмаст тэнгэр түүнд зөвхөн гучин нэгхэн жилийн богино цагийг соёрхсон байхад, тэр харин хурмаст тэнгэрт уран зохиолын өнөдийн вант гүрнийг буцаан өгчээ» [Дорнотэнгэр 2018: 179] хэмээн «Дусал усны ачийг дундаршгүй ундрах булгийн дайтай хариулах» гэдэг, Хятадын аман зохиол, хуучны алдарт сургаалын зохиолын өгүүлэмжтэй холбон өгүүлсэн байдаг. Тэгвэл орчин цагийн Монголын нэрт түүхч, Төрийн шагналт, Шинжлэх ухааны гавьяат зүтгэлтэн, Академич Ш. Нацагдорж гуай байгаагүй бол, уран зохиолын өнөдийн тэр, агуу вант гүрнийг мэдэхгүй өнгөрч, болох байлаa. Энэ тухай тэмдэглэсэн Ш. Нацагдоржийн нэгэн баримтыг хамтдаа сөхье.

«Нацагдорж гуай нас бараад хэд хонож байтал Шинжлэх ухааны хүрээлэнд тэр үед ажиллаж байсан, Нацагдорж гуайтай дотно нөхөрлөдөг Сандаг: “- Хөөрхий Нацагдорж маань нас бараад хэд хонолоо. Түүний өнөө ном зохиол нь хаана, юу болсныг хэлж мэдэхгүй байна. Хоёул явж сураглаж эрэх юм биш үY!” гэхэд би дуртайяа зөвшөөрч билээ. Чухам хэдний өдрийг мартжээ. (Долдугаар сарын сүүлчээр юмсан) Сандаг,

«Сүүлийн үед Нацагийн сууж байсаи газрыг би мэднэ, юу ч болсон тэнд очъё” гэж намайг дагуулан явлаа. Хуучин «Ард” кино театрын урд гудамжаар явсаар «Спартак” нэртэй хоёр давхар зочид буудалд хүрч ирлээ. Энэ бол тэр үеийн Улаанбаатар хотын хамгийн том, ганц зочид буудал байсан юм. Сандаг намайг дагуулан, шууд, хоёрдугаар давхарт гарч, баруун тийш эргэн хойш харсан нэгэн өрөөнд оров. Тэр, энд нэг бус удаа ирж байсан нь тодорхой байлаа. Өрөөнд бяцхан ширээ, нэг сандал, хөх даалимбан гадартай нэг гудастай, цэрэг төмөр орноос өөр 
юу ч байсангүй. Бид хоёр баахан гайхан зогсож байгаад орны доогуур шагайж үзвэл, нэгэн дөрвөлжин модон хайрцаг байсан. Түүнийг гаргаж үзвэл Нацагдоржийн бүх гар бичмэл, фото зураг байлаа. Бид хоёр, тэр бүхнийг авч, шууд Шинжлэх ухааны хүрээлэнгийн Хэл зохиолын тасагт аваачиж, тоо ёсоор нь тушаасан билээ. Хэрэв бид хоёр тэгж, эрж явж, олоогүй бол Нацагдорж гуайн гар бичмэл яах ч байсныг хэн мэдэх вэ? Миний бие Нацагдоржийн шавь байсны хувьд түүний төлөө хийсэн өчүүхэн зүйл минь энэ билээ» [Нацагдорж 1990, 138-139].

Ингэж Монголын орчин үеийн Их зохиолчийн зохиол бүтээлийн гар бичмэл «аврагдаж», өдгөө түүний зохиол бүтээлүүд гадаад, дотоодод олонтаа хэвлэгдэн түгсэн байна. Энэ үйл хэрэгт эрдэмтэн судлаач Б. Содном [Содном, 1966], Л. Балдан [Балдан, 1988], С. Лочин [Лочин, 1981, 1999], Д. Цэдэв [Цэдэв, 2016], Ч. Жачин [Жачин, 1987, 1988, 1991] нар чухал амжилт олсон бөгөөд Д. Нацагдоржийн зохиолын гар бичмэлийн талаарх суурь судалгааны олон бүтээлийг эдгээр эрдэмтэд бичсэн байдаг билээ.

Өдгөө Д. Нацагдоржийн зохиол бүтээлтэй эдгээр судлаачдын бүтээлээр дамжин танилцдаг нь дээрх судлаачдын бүтээл нь үнэ цэн бүхий чухал гарын авлага болсныг батлан харуулна. Ялангуяа эдгээр эрдэмтдийн Д. Нацагдоржийн зарим гол, онц сонирхолтой зохиол бүтээлийн тухайд дэвшүүлсэн, хувь судлаачийн үзэл баримтлалууд нь энэ цаг үед, Д. Нацагдорж уран бүтээлийг судлахад: 1) Онолын, 2) Арга зүйн, 3) Мэргэжил мэдлэгийн, 4) Харьцуулал, зэргэцүүллийн, 5) Гаргалгаа дүгнэлтийн ... зэрэг олон талын өв туршлага болсоор байна. Үүнийг Д. Нацагдоржийн «Харанхуй хад” зохиол дээр ажилласан туршлагаас харж болно.

Д. Нацагдоржийн «Харанхуй хад» өгүүллэгийн гар бичмэл эх Монгол Улсын ШУА-ийн ХЗХ-ийн сан хөмрөгт хадгалагдаж байна. Судлаачид «Харанхуй хад» өгүүллэгийн гар бичмэл эх дээр ажиллаж, улмаар өгүүллэгт гарч буй нэгэн дүрийн нэрийг зохиолын агуулга мөн чанартай холбон үзсэн нь тун сонирхолтой асуудлыг дэвшүүлсэн юм. Тухайлбал, «Харанхуй хад» өгүүллэг нь: «Зуны шөнө богино тул, өглөөний найман цагт нар нэгэнт дээр гарчээ. Унтсан нойрноос арайхан сэрмэгц, нэг янжуур асааж, шившив. Чилсэн биеийг талбируулан түр зуур хэвтэхийн завсар энэ өдрийн элдэв хэргийг бодох бөгөөд өдрийн тэмдэглэлийн дэвтрээ дэрэн доороосоо авч үзвэл, химчик харандаагаар бичсэн хэдэн үсэг, бараг бүрэг үзэгдэхэд, түүнийг 
шүлсээрээ норгон улмаар ажиглавал: “Наймдугаар сарын гучны Бямба гариг, Харанхуй хад Нина” хэмээх хэдэн үгсийг тэмдэглэсэн байх нь утга ба учир тодорхойгүй, юун тухай бичсэн нь огт мартагдсан тул дахин нэг удаа алгуурхнаар уншиж эцсийн үсэг дээр нь хүрвээс, Ина хэмээх нь миний хуучин амраг охины нэр, цахилгаан адил хоромхон зуур, миний тархины дотор гэрэлтсэн бөгөөд мөнхүү охиныг хэдийнээ хайлаас модны сүүдэрт тэврэн үнсэж агсан цаг гэнэт санагдан, сормуусны сүүдэр дор үзэгдэхүй дор даруй сэтгэл хөдөлж, улмаар эрт ба эдүгээ хол ба ойрыг улируулан бодох тутам, ийн тийн уяран мэлмэрч, зүүд мэт болон зэрэглэсээр, агшин зуур үүргэлсэн нь, татаж буй тамхины үнс хэнхдэг дээр унахад, гэдрэг цочин сэрэхүй лүгээ уг тэмдэглэлийн учир утга юу болохыгэргэцүүлэв. Үүнд, юуны урьд, би түүнтэй хязгааргүй янаглан ханилсан боловч, дараагаар хоёр бие уул далайн тэртээ энэтэйд завсарлагдан, сэтгэл зүрх ташаалагдсан бөлгөө. Хожим хайртай Ина хаана одсоныг мэдэхгүй, хэдийгээр эрэн сурвалжилсан боловч эс олоод алмайран гайхсаар агсан нь гэтэл энэ өглөө санамсаргүй өдрийн тэмдэглэлийг үзэхэд үл мэдэгдэх утга бүхий хэдэн үгсийн дотор түүний нэр байхыг үзээд, зүрхний дотор зул ноцвой» [Нацагдорж 2016: 3] хэмээн эхэлдэг билээ. Эхлэл хэсгийн энэ агуулга нь: Зохиолын би баатар, 8-р сарын 30-ны Бямба гаригийн өглөө, сэрээд, тамхиа татах зуураа, дэрэн доороосоо өдрийн тэмдэглэлийн дэвтрээ авч үзтэл «Наймдугаар сарын гучны Бямба гариг, Харанхуй хад Нина» хэмээх хэдэн үг бичсэнээ олж үзэж байна. Ингээд би баатар «Ина гэж юу билээ?», «Хэн билээ?» гэж бодоход, хуучин амраг охины нэр нь, түүнтэй сайхан байсан цаг нь санагдаж, тийнхүҮ зүрх, сэтгэл нь догдолж байгаа тухай юм.

Зохиолын гар бичмэл эхэд, «Нина» гэх үг ердөө ганц л, удаа «Наймдугаар сарын гучны Бямба гариг, Харанхуй хад Нина» гэж гарна. Харин «Ина» гэх үг 12 удаа гарна.

Үүнийг судлаач Б. Содном хамгийн эхний «Нина» хэмээх үгээр нь авч үзэн, эл зохиолын агуулгыг, Д. Нацагдоржийн хувийн амьдралтай холбон тайлбарласан байдаг. Улмаар «Зохиолын эх бичгийн хажуу талд “Энэ зохиолыг Нинаг хойд зүг явснаас хойш бичсэн тул, үнэндээ 1936 онд бичжээ. Харин уг оныг нааш татаж бичсэн байна” гэж хөх бэхээр бичжээ» [Цэдэв 2016: 385] Эл цэнхэр бэх нь «Харанхуй хад» зохиолын гар бичмэл эх дээр байгаа хамгийн эхний «Ина» хэмээх үгийн монгол бичгийн титмийн зурлагын өмнөх цэгийг бичсэн бэхтэй төстэй байдаг. 
Тэгвэл судлаач Ч. Жачин «Зохиолын эх бичигт хийсэн ажиглалт, тэмдэглэл» бүтээлдээ «Харанхуй хад»-ын тухайд сонирхолтой үзэл баримтлалыг дэвшүүлсэн юм. Судлаач, өгүүллэгт гарч буй «... Үүнд юуны урьд мөнхүү бичсэн хүний нэр дээрээс эхлэн бодвоос Ина хэмээх нэгэн залуу цэвэрхэн охин бөгөөд долоог жилийн урьд би түүн лүгээ хязгааргүй янаглан танилцсан боловч, дараагаар хоёр бие уул далайн тэртээ, энэтэй дор завсарлагдаж сэтгэл зүрх ташаалагдсан бөлгөө» [Нацагдорж 2016: 3] хэмээх өгүүлэмжийг, уг зохиолыг бичсэн 1930 оны 8-р сарын 24-ны цаг хугацаатай холбон, 1930 оноос өмнөх долоон жил гэдэг нь 1923 он болох тул, энэ үед Д. Нацагдорж анх уран бүтээлийн гараагаа эхэлсэн. Тийм болохоор, «Ина» гэдэг үГ нь өгүүллэгийн төгсгөлийн шүлэг:

«Харанхуй хадан дунд хашралтай бөгөөд аюултай

Харин түүний байдлыг хасын охин сонирхмой

Яруу найруулга хэмээгч нь ертөнц дор гайхамшигтай бөгөөд

Ина охины адил идэр хүний сэтгэлийг булаана" [Нацагдорж 2016: 3] гэсэн дөрвөн мөртийн «Яруу найруулга хэмээгч нь ертөнц дор гайхамшигтай бөгөөд Ина охины адил идэр хүний сэтгэлийг булаана» хэмээх төгсгөлийн хоёр мөрийн «iragu nairuulga» гэдэг үгийн товчлол буюу «і-nа» юм гэсэн үзэл баримтлалаа дэвшүүлсэн юм.

Тэгвэл судлаач С. Байгалсайхан «“Харанхуй хад” өгүүллэгийн тухай» өгүүлэлдээ зохиолын утга санаа, өгүүлэмжид тулгуурлан, зохиолчийн нийгмийн үйл ажиллагаа, зохиолчийн үзэл санааны харилцаа холбооны талыг нээж илрүүлсэн шинэ үзэл баримтлал дэвшүүлсэн юм. Судлаач, «Д. Нацагдорж 1923 оны 8 сард Орос улсын Дорно дахины их сургуулийн оюутан Казакевичтэй хамт Нацагдорж одоогийн Хэнтий, Дорноговь аймгийн зааг дахь Бүсийн чулуу гэдэг газар эрдэм шинжилгээний албан томилолтоор явжээ. Энэхүу томилолтоор явуулах тогтоолд ...Сэцэн хан аймгийн Ахай бэйсийн хошууны нутаг дахь Бүсийн чулуу хэмээх газраа бүхий хэсэг байшин хэмээх эвдэрхий балгасны бичигт чулууны бичгийг орос оюутан Казакевич, төвийн хорооны нарийн бичгийн дарга Нацагдорж нарыг илгээж, хэвлүүлэн авсугай хэмээн тогтов... гэсэн баримт түүхийн архивт байгаа. Владимир Александрович Казакевич бол 1896 онд Санкт-Петербург хотод түшмэдийн гэрт төрсөн, тайж угсаатай хүн. 1917 онд хувьсгалт цэргийн алба хаасан хүн байсан. ЭнэхүҮ үйл явдал нь нэгд, Нацагдорж анх удаа гадаадын хүнтэй нүүр тулан уулзан учирч, танилцсан. Мэдээж энэ хувьсгалт үзэл санааны тухай гадны нөлөөлөл 
авсан байж таарна. Хоёрт: 1923 онд интернационалын дэргэд «СИМ» (Социалистический интернационал молодежи) буюу «Залуучуудын социалист интернационал” байгуулагджээ. ЭнэхүҮ үйл явдал нь хувьсгалт намын дэргэд залуучуудын эвлэл, пионерийн байгууллагыг санаачлан байгуулж байсан Нацагдоржид томоохон нөлөө үзүүлсэн нь дамжиггүй. ИйнХүY 7 жилийн өмнө анх дам болон шууд хэлбэрээр олон улсын залуучуудын интернационалч үзлийг хүлээн авсан нь түүний амьдралд томоохон байрыг эзэлж, үйл ажилд нь тусгалаа олжээ. Харин аливаа үзэл бодол, байгууллага, эд юмыг хүнчлэн үзүүлдэг туршлага Д. Нацагдоржийн зохиолд маш элбэг байдаг. Тухайлбал, 1930 онд бичсэн «Залуучуудын үнэн» нийтлэлд:

«Ийм нэгэн гайхамшигтай нөхөр, нэр залуучуудын үнэн билээ

Эдүгээ нас арван тавтай бөгөөд өсч төлжих нь чийрэг

Өнгө бүрийн үзэсгэлэнт зүйлээр биеэ чимсэн бөгөөд

Зүйл бүрийн сонин юмсыг уулзах бүр уламжилна» гэж сониныг арван таван настай хөвгүүнээр төлөөлүүлэн үзүүлсэн байна. Тиймээс ч интернационалыг залуу охиноор амьдчилан үзүүлсэн нь ойлгоход хэцүҮ асуудал биш юм. Харин «Ина» гэдэг нэрийн товчлолын хувьд тайлбар өгөхөд мөнхүү гадаадын элдэв үгсийг зохиолч өөрийнхөөрөө бодож товчлон хэрэглэдэг туршлага түүний уран бүтээлд байсан. 1930 онд бичсэн олон улсын залуучуудын өдөрт зориулсан нэгэн шүлэгтээ тэрээр «МЮД» буюу «Международный Юношеский День» гэж нэрлэжээ. Ингэхлээр Интернационалыг «Ина» гэж товчилсон байх бүрэн магадлалтай юм» [Байгалсайхан 2004: 39] гэсэн байдаг.

Энэ бүхнээс үзэхэд Монголын уран зохиолын нэгэн сонгодог «Харанхуй хад» өгүүллэгийн мөн чанарыг тодруулахад эдгээр судлаачид үнэт хувь нэмэр оруулсан байна.

Д. Нацагдорж «Харанхуй хад» өгүүллэгтээ зүүд, зөн совин, болзолт дүрслэлийг баялаг хэрэглэн, уран сэтгэмжээр үйл явдлыг нь өрнүүлэн бичсэн байна. «Харанхуй хад» нь өрнө дахины уран зохиолын шинэ хэв маяг, модернизм, постмодернизмын маягтай, ялангуяа символизмын аргуудыг хэрэглэсэн, үүний зэрэгцээ архитеп болон домог үлгэрийн уран сайхны сэтгэлгээ (poetic of myth, мифопоэтик)ний зүйлсийг олонтаа шигтгэж өгсөн юм. Мөн түүнчлэн «Харанхуй хад»-д хүний оршихуйн гүн ухааны асуудлууд, хүний аж байдал, энэ хорвоо ертөнцийн жам ёс, түүний гашуудалтай хийгээд эмгэнэлтэй талыг өвөрмөцөөр өгүүлсэн юм. Өгүүллэгийн энэ шинж нь, уншигчдыг цочоох, гайхшралд оруулах, уйлуулах, энэлгэх, шаналгах, дурыг нь 
гутаах зэрэг сэтгэлийг хөдөлгөж, сэтгэлгээнд хүчтэй нөлөө үзүүлдэг болохоор «Харанхуй хад»-ыг бусад олон зохиолтой харьцуулан зэрэгцүүлэхэд утга санаа, туурвил зүйн арга барилын хувьд огт өөр, цоо шинэ байдаг ба өнөө хүртэл уншигдсаар байдгийн нууц нь үүнд оршино. Эл нууцыг тодруулахад бичвэрийн судалгаа хийсэн эдгээр судлаачдын судалгаа чухал үнэ цэнтэй.

\section{Ном зүй}

1. Байгалсайхан C. «Харанхуй хад» өгүүллэгийн тухай // Байгалсайхан С. Утгын чандмань. Улаанбаатар: “Бемби сан” хэвлэлийн газар, 2004. $270 \mathrm{x}$.

2. Балдан Л. Д. Нацагдоржийн гар бичмэл / Яруу найргийн зохиолын галиг тайлбар, харьцуулалт, толь бичгийг Л. Балдан хийв / Corpus scriptorium mongolorum. Tom XXII. Fasc. 1. Улаанбаатар: ШУА-ийн Хэвлэлийн хороо, 1988. 234 х.

3. Дорнотэнгэр. Нисэн одсон болжмор. Улаанбаатар: "Бемби сан" хэвлэлийн газар, 2018. 200 х.

4. Жачин Ч. Д. Нацагдоржийн эх бичигт хийсэн ажиглалт, тэмдэглэл. Улаанбаатар: Улсын хэвлэх үйлдвэр, 1987. 128 х.

5. Жачин Ч. Д. Нацагдоржийн гар бичмэлийн эхийн судалгаа. Улаанбаатар: Улсын хэвлэх үйлдвэр, 1988. 256 х.

6. Жачин Ч. Текстологическое исследование рукописей Дашдоржийна Нацагдоржа. Дисс. на соискании степени Ph.D. Улаанбаатар, 1991. 160 c.

7. Лочин C. Основные методологические принципы текстологии современной монгольской литературы (на основе публикаций произведений Д. Нацагдоржа). Дисс. на соискание степени Ph.D. Улаанбаатар, 1981. 178 c.

8. Лочин С. Монголын уран зохиолын бичвэрийн судалгаа. Диссертаци. Улаанбаатар, 1999. 251 х.

9. Нацагдорж Д. Бүрэн зохиол. III боть / Төмөржин эрхлэн найруулав. Хөххот: “Алсын бараа” хэвлэлийн хороо, 2016. 448 х.

10. Нацагдорж Д. Бүрэн зохиол-Хүүрнэл зохиол / Удиртгал, тайлбар бичиж эрхэлсэн Д. Цэдэв. Улаанбаатар: “Цагаан бамбарууш” хэвлэлийн газар, 2016. 503 х.

11. Нацагдорж Ш. Миний мэдэх Нацагдорж // Д. Нацагдоржийн уламжлал, утга зохиолын зангилаа асуудлууд. Улаанбаатар: Улсын хэвлэх үйлдвэр, 1990. 180 х.

12. Содном Б. Д. Нацагдоржийн намтар зохиол. Улаанбаатар: Улсын хэвлэх үйлдвэр, 1966. 293 х. 
13. Цэдэв Д. Их Нацагдоржийн «Хэлхээгүй сувд»-ын учиг. Улаанбаатар: “Соёмбо принтинг” хэвлэлийн газар, 2016. 173 х.

\section{References}

1. Baigalsaikhan S. «Kharankhui khad» egyYllegiin tukhai // Baigalsaikhan S. Utgyn chandman'. Ulaanbaatar: "Bembi san" khevleliin gazar, 2004. 270 kh. [In Mong.].

2. Baldan L. D. Natsagdorzhiin gar bichmel / Yaruu nairgiin zokhiolyn galig tailbar, khar'tsuulalt, tol' bichgiig L. Baldan khiiv / Corpus scriptorium mongolorum. Tom XXII. Fasc. 1. Ulaanbaatar: ShUA-iin Khevleliin khoroo, 1988. 234 kh. [In Mong.].

3. Dornotenger. Nisen odson bolzhmor. Ulaanbaatar: "Bembi san" khevleliin gazar, 2018. $200 \mathrm{kh}$. [In Mong.].

4. Zhachin Ch. D. Natsagdorzhiin ekh bichigt khiisen azhiglalt, temdeglel. Ulaanbaatar: Ulsyn khevlekh Yildver, 1987. 128 kh. [In Mong.].

5. Zhachin Ch. D. Natsagdorzhiin gar bichmeliin ekhiin sudalgaa. Ulaanbaatar: Ulsyn khevlekh yildver, 1988. 256 kh. [In Mong.].

6. Zhachin Ch. Tekstologicheskoe issledovanie rukopisei Dashdorzhiina Natsagdorzha. Diss. na soiskanii stepeni Ph.D. Ulaanbaatar, 1991. 160 s. [In Russ.].

7. Lochin S. Osnovnye metodologicheskie printsipy tekstologii sovremennoi mongol'skoi literatury (na osnove publikatsii proizvedenii D. Natsagdorzha). Diss. na soiskanie stepeni Ph.D. Ulaanbaatar, 1981. 178 s. [In Russ.].

8. Lochin S. Mongolyn uran zokhiolyn bichveriin sudalgaa. Dissertatsi. Ulaanbaatar, 1999. $251 \mathrm{kh}$. [In Mong.].

9. Natsagdorzh D. Byren zokhiol. III bot' / Temerzhin erkhlen nairuulav. Khekhkhot: "Alsyn baraa" khevleliin khoroo, 2016. 448 kh. [In Mong. script].

10. Natsagdorzh D. Byren zokhiol-KhyYrnel zokhiol / Udirtgal, tailbar bichizh erkhelsen D. Tsedev. Ulaanbaatar: "Tsagaan bambaruush" khevleliin gazar, 2016. $503 \mathrm{kh}$. [In Mong.].

11. Natsagdorzh Sh. Minii medekh Natsagdorzh // D. Natsagdorzhiin ulamzhlal, utga zokhiolyn zangilaa asuudluud. Ulaanbaatar: Ulsyn khevlekh Yildver, 1990. $180 \mathrm{kh}$. [In Mong.].

12. Sodnom B. D. Natsagdorzhiin namtar zokhiol. Ulaanbaatar: Ulsyn khevlekh Yildver, 1966. 293 kh. [In Mong.].

13. Tsedev D. Ikh Natsagdorzhiin «Khelkheegyi suvd»-yn uchig. Ulaanbaatar: "Soembo printing" khevleliin gazar, 2016. 173 kh. [In Mong.]. 